\title{
Development of Outsourcing in the Customs Sphere
}

\author{
Roman V. Fedorenko ${ }^{1}$ \\ ${ }^{1}$ Samara State University of Economics, Russian Federation \\ Correspondence: Roman V. Fedorenko, Sovetskoi Armii Str. 141, Samara, 443090, Russian Federation. E-mail: \\ fedorenko083@yandex.ru
}

Received: June 26, 2014 Accepted: July 16, 2014 Online Published: September 28, 2014

doi:10.5539/ass.v10n20p202 URL: http://dx.doi.org/10.5539/ass.v10n20p202

\begin{abstract}
The article determines the role of customs authorities in organization of international economic activity. The peculiar features of services rendered in the customs sphere were studied, and a group of services rendered by specialized intermediaries was identified. These services were characterized and the possibility of their outsourcing was considered. The article also considers the advantages and deficiencies of using full, partial, and controlled outsourcing. A model of stage-by-stage implementation of controlled outsourcing in the customs sphere was developed, and approaches to evaluating the efficiency of outsourcing in the customs sphere were suggested.
\end{abstract}

Keywords: international economic activity, services in the customs sphere, customs dealers, outsourcing, controlled outsourcing

\section{Introduction}

During the recent two decades, one of main lines of development of the modern economics has been the drastically growing sphere of services. According to the leading world-known expert in marketing Ph. Kotler, "A service is an act of performance that one party can offer to another" (Kotler, 2004). Robert Johnston и Graham Clark in their article Service Operations Management: Improving Service Delivery suggested categorization of this activity by distinguishing the main types of services:

- business-to-customer services (e.g. financial services, retail, leisure);

- business-to-business (e.g. consultants, office equipment provision and support, communications);

- internal services (e.g. personnel, IT services);

- public services (e.g. police, education, health services);

- non-for-profit services (e.g. charities, fath organizations, aid organizations) (Johnston \& Clark, 2005).

Services of public bodies hold special place in this sequence, and should include customs activity to our opinion. The Russian researcher of the problems in the sphere of management of customs activities S. V. Baramzin believes that "as applicable to the customs authorities, customs services should be understood as the result of labor", where "customs activities is a certain public service rendered to the participants of the international economic activity" (Baramzin, 2004).

Customs authorities play an important role in development of foreign trade operations. In the course of international economic activity, participating companies face the necessity to comply with a wide range of statutory requirements prescribed by the customs legislation. The fiscal function is deemed by the government as the most important function of customs authorities. The research of the World Customs Organization carried out in 73 countries revealed that in 2010, the amount of customs duties equaled to $11.48 \%$ of the budget revenues of the studied states (WCO, 2014). In their turn, expectations of the business community, namely consumers of customs services, reside in minimizing the influence of customs administration of procedures involved in delivery of goods across the border on the overall cost of trade activity (Grainger, 2014).

Customs formalities are a single option duty of a foreign trade operator who intends to exercise their right to transfer goods and vehicles across the customs border. Currently, the majority of foreign trade operators do not make use of the existing opportunities of expediting and facilitating the process of customs clearance and customs control. Companies engaged in international economic activity face a large number of problems, which 
normally cannot be solved unassistedly. Such problems include abidance by all requirements prescribed by the customs legislation, as well as solution of any economic issues associated with transportation and storage of goods. The issues of arrangement of physical movement of international goods traffic are rather well studied by Russian and foreign researchers (Waters, 2003; Khramtsova, 2010). At the same time, organization of customs clearance is more rarely considered in theoretical scientific research.

Many foreign trade operators prefer to avoid solving problems related to interaction with customs authorities independently, but to apply to professionals for help. A traditional mechanism of solving this task is the outsourcing. Scientific literature provides various approaches to interpreting this concept. A classic definition is provided by Brian J. Heywood: "outsourcing is the transferring of an internal business function or functions, plus any associated assets, to an external supplier or service provider who offers a defined service for a specified period of time at an agreed but probably qualified price" (Heywood, 2002). The American economists R. Chapman and K. Andrade emphasize that this term is used as an umbrella for highlighting various lines of business activity (Chapman \& Andrade, 1998). The Canadian economist G. Cassidy thought the main peculiar feature of outsourcing is assignment of the contract to a third party and introduced the term contracting out (Cassidy, 1994).

The contemporary scientific literature shows insufficient consideration of the theoretical principles and mechanisms of rendering services in the customs sphere. Despite the considerable interest of scientists to this issue, the issues of application of outsourcing with regard to services in the customs sphere require elaboration. This article studies the conventional approach to outsourcing, which is insufficiently efficient in terms of arrangement of interaction between foreign trade operators and the customs, and development of basic principles of controlled outsourcing, which would allow cutting costs at passing customs procedures.

\section{Methodology}

Scientific papers of the leading Russian and foreign scientists related to the problems associated with rendering services in the customs sphere, carrying out international economic activity of companies, materials of international, all-Russian and regional scientific and practical conferences and seminars, publications in periodicals, materials of studies carried out by international organizations (the World Bank, the World Customs Organization) were the theoretical and methodological bae of the article.

This article uses provisions of effective laws and regulations of the Russian Federation, orders of the President of the Russian Federation, decrees and instructions of the Government of the Russian Federation, legal and executive directives of the Federal Customs Service of Russia related to carrying out international economic activity and its customs regulation, activity of customs authorities, as well as customs brokers, owners of temporary storage warehouses and customs warehouses, and customs carriers.

In the process of the research, we used: the dialectic method of cognition, the comprehensive approach to studying the identified research subject, the methods of systemic, structural, functional, comparative, logic, economical-statistical, and root cause analysis, and graphical methods.

\section{Results}

Foreign trade operators face problems considerably different from the problems that those companies carrying out their activity within one country face. As a result, they need specific services related to interaction with customs authorities.

The services providing for international economic activity can be broken up into four main groups by their role in maintaining the goods traffic:

- services related to conclusion of international trade transactions and their and financial and legal support;

- services related to logistic support of foreign trade transactions;

- services related to abidance by the requirements of domestic legislation on state regulation of foreign trade;

- services in the customs sphere related to compliance with the requirements of the customs legislation.

Depending on the services provider, we can distinguish services provided by customs authorities and services in the customs sphere provided by persons who are customs intermediaries.

The concept of customs services with account of their role and importance can be defined as a total of actions to be performed by customs authorities with the purpose of providing for movement of goods and vehicles across customs borders of countries in the course of transportation of the goods from the seller to the buyer in compliance with the requirements of these countries. 
The concept services in the customs sphere should be defined separately as the activity of companies authorized to perform commercial activity in the customs sphere with the purpose of supporting movement of goods across the customs borders of countries in the course of transportation of the goods from the seller to the buyer in compliance with the requirements of these countries.

The foreign trade development and the respective growth of budget revenues are impossible without existence of an ultimately efficient system of movement of goods and services across the customs border. Customs services have the main objective of preventing violations and creating opportunities for expedition of goods traffic by developing and implementing such progressive methods of customs clearance procedures as e-declaration, pre-declaration, etc. At the same time, services in the customs sphere (rendered to importers and exporters by specialized companies) are dedicated to use all available opportunities and finding the optimal way of clearance in each particular case.

The typical peculiar feature of services in the customs sphere is that companies rendering such services act under the basic principle of the Kyoto Convention - maximum assistance to foreign trade without any harm to the customs control efficiency. Thus, development of such services can provide for implementation of the mentioned tasks at minimum financial and time expenditures for the importers and exporters.

Services in the customs sphere are rendered by specialized companies authorized to perform the said activity in compliance with the existing requirements of the Customs Code. These companies can be broken up into four categories: customs brokers, customs carriers, temporary storage warehouses (TSW), and customs warehouses $(\mathrm{CW})$.

Customs clearance services include the following main procedures: categorization of goods according to the Foreign Economic Activity Commodity Nomenclature (FEACN), determination of the customs value of goods according the FEACN, determination of the customs treatment, filling out goods declaration (GD), filling out documents related to the GD, calculation and payment of customs duties in time. The demand for additional advice on certain issues of customs clearance is met in the form of information support of clients with regard to general and particular questions about customs clearance, verification of correctness and validity of filling the documents, providing recommendations on settlement of disputable issues. The services considered above are an integral part of organization of foreign trade.

In certain cases, the necessity emerges to arrange carriage or storage of goods under customs control. Customs carriers can render services of arranging carriage of goods under customs control, securing the internal customs transit treatment, insurance, and cargo escorting. Storage of goods under customs control is arranged by temporary storage warehouses and customs warehouses, which provide a particular sequence of warehousing services.

Interaction with customs authorities is one of the most important issues in the operation of any company engaged in foreign economic activity. Only large foreign sales corporations can afford a division specializing in interacting with customs authorities. Nevertheless, they also currently tend to use intermediaries' services.

The services of intermediaries (i.e. customs brokers) are currently the most popular and eagerly sought ones amidst all services rendered in the customs sphere. The article Customs Brokerage Services and Trade Facilitation: A Review of Regulatory Coherence notes the importance of the activity of customs brokers for both the state and the business community: Customs brokers highlight their role as intermediaries in the whole customs process wherein they represent both the traders and the government. They consider themselves as upholding the interest of the government because they ensure the collection of the right amount of duties and taxes. They argue that since they have the expertise on trade laws as well as tariff and customs procedures, they can readily adapt to the changing needs of the international trading community. They believe that their knowledge of customs administration rules and regulations equips them with the proper tools to question and counter any arbitrary change on the procedures, which may disadvantage either the government or the traders (Llanto et al., 2013).

Interaction of importers and exporters with customs brokers is based on the outsourcing principle. The concept of outsourcing as a principle of the new management strategy was created in 1963 by the E1ectronic Data System Company (EDS), which specialized in outsourcing of digital technologies, or IT outsourcing. However, outsourcing became an object of scientific research only in 1980s-1990s. From that time, they started publishing scientific publications, with which economists and experts using various models tried to find the optimal strategy of outsourcing implementation, as well as publications dedicated to various aspects of outsourcing application by a company. Having emerged in American economic publications, the term outsourcing settled in the vocabulary of the majority of businesspersons of industrially developed countries (Anikin, 2003). 
Outsourcing of services in the customs sphere has certain singularities. Traditional outsourcing is delegation of functions, which a company is able to perform itself (accounting, carriages, cleaning, etc.), but seeks economic benefit. Outsourcing of services in the customs sphere differs from them by the fact that the company is not able to arrange declaration by itself, which is the reason of its assignment of this work to a customs broker. As a result, the foreign trade operator loses control over the process of customs clearance and is not able to evaluate its efficiency.

Customs brokers are not interested in application of advanced methods of declaration at performing customs clearance. By registering each unit of goods in a separate declaration, it gains maximum revenue. As an example, we can provide the experience of arranging international economic activity of enterprises of the Samara Region. The largest exporters of the Samara Region perform 8-10 thousand shipments a year. Average cost of one export declaration for goods is 10,000 rubles. If a separate declaration for each shipment is registered, the broker will gain 80-100 million rubles. At the same time, usage of the advanced methods of declaration prescribed by the Customs Code (preliminary GD, periodical GD, incomplete GD) enables clearance of exported goods with a considerably less number of documents (100-150 GDs for 8-10 thousand shipments). And this scheme is so widely applicable that even at a conservative estimate; enterprises of the Samara Region pay extra dozens of millions of rubles to customs brokers.

To our opinion, full outsourcing is reasonable only for start-up importers and exporters, whose number of GDs is very low. As the international economic activity of an enterprise is formed and intensifies, the number of rendered services should grow along with the number of GDs. Otherwise, as the foreign trade turnover of the company grows, the costs for customs clearance will be inevitably growing in proportion. Therefore, the best strategy will imply partial outsourcing of the declaration functions instead of full one. However, we do not mean the conventional partial outsourcing assuming allocation of equal functions between tge client and the contractor, but the contemporary type of outsourcing, which allows strategic control over the whole procedure of customs clearance.

One need to keep in mind that selection of the contractor should not be based only on economic motives; the risks of consequences associated with selection of a wrong partner must also be taken into account. At the same time, as German economists Henkel C. B., R. Hesch and F. Kroger noted, real competitive advantages for the participants of inter-company cooperation occur only when both parties are actively involved in the process of production of added value (Henkel et al., 2000).

It is reasonable to transfer to customs brokers only the technical part of declaration, and the determination of the scope of services rendered by the broker, the treatment and the order of customs procedures should remain the prerogative of the foreign trade operator. Such outsourcing is to be defined as controlled (Fedorenko, 2008).

Controlled outsourcing in the customs sphere is optimization of the activity of an enterprise with regard to customs clearance, which aims cutting costs through transferring technical (secondary) functions to professional brokers and focusing own efforts and means on solution of strategic tasks in this sphere.

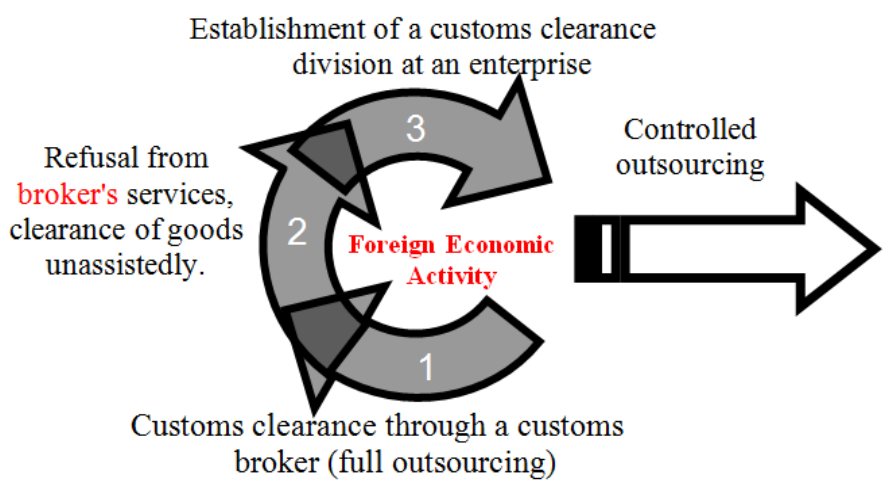

Figure 1. The evolution of the system of customs clearance of an enterprise engaged in international economic activity

In the practice of an enterprise, the controlled outsourcing is implemented by professional actions of the company's own specialist or the department of customs clearance. Such organization will provide for the synergistic effect of delegation of routine functions and of optimal customs clearance. In this case, the customs broker will be lodging GDs in the form required by the enterprise, and its own employees relieved from routine work will be able to focus their efforts on seeking opportunities for cost cutting. 
In the beginning of its operation, any company facing the necessity to arrange customs clearance of goods uses the services of customs brokers, which means full outsourcing. Further development of the customs clearance function at the company proceeds in several subsequent stages. The finish of the evolution is implementation of controlled outsourcing (Figure 1).

The typical feature of full outsourcing is that as the goods traffic grows, the costs for customs clearance will be growing in direct proportion to the growth, as the customs broker in case of growing supplies will simply lodge a larger number of GDs without using periodical declarations and other methods of cutting the client's costs. Use of controlled outsourcing will allow the enterprise developing and implementing the most efficient system of customs clearance. Implementation of controlled outsourcing requires initial investment, but will generate considerable profit later.

The article provides comparative assessment of costs of a foreign trade operator with regard to using full and controlled outsourcing, which allowed developing a mathematical model of the costs dependences. The results of the study are provided in Figure 2.

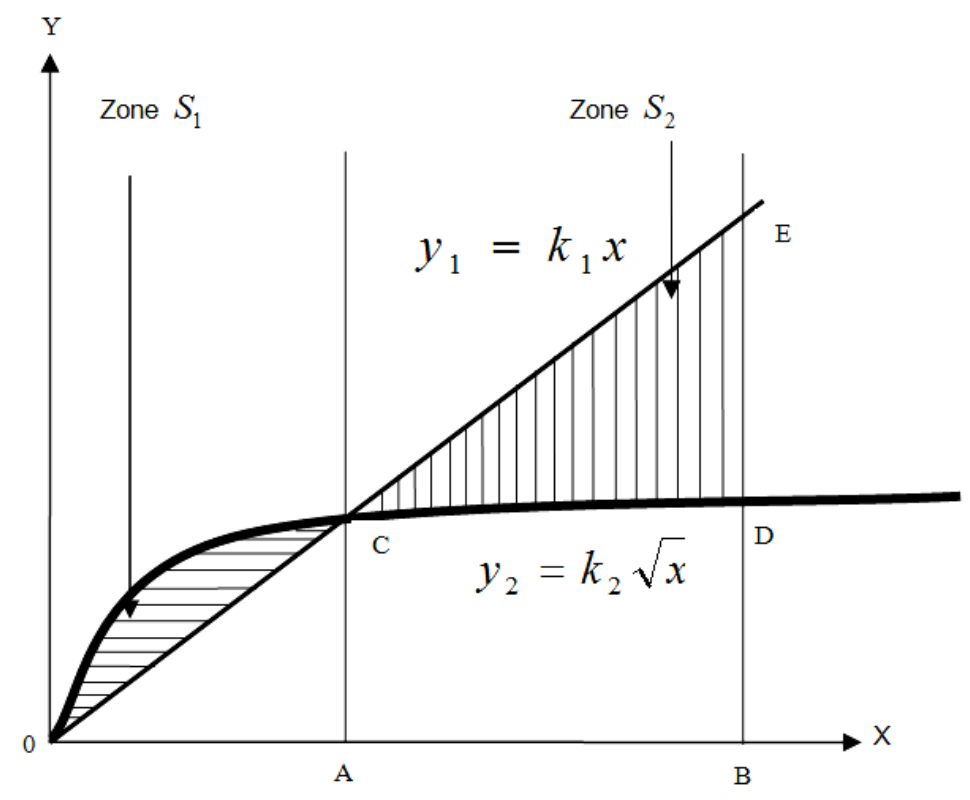

Figure 2. The advantages of controlled outsourcing

In Figure 2, the curve $y_{2}$ drawn over the straight line $y_{1}$ denotes the advantages of controlled outsourcing of customs clearance services, where:

The $Y$-axis is the costs of the enterprise in thousand rubles.

The $X$-axis is the number of cleared goods under foreign trade operations in pcs.

The straight line $y_{1}=k_{1} x$ is full outsourcing.

The curve $y_{2}=k_{2} \sqrt{x}$ is controlled outsourcing.

The area $S_{1}$ is the area of initial investments

The area $S_{2}$ is the area of profit.

As the number of cleared goods exceeds the value in the point $A$, the controlled outsourcing generates profit for the enterprise. Theoretically, this model is infinite, but practically, it is limited to the production capacity of the enterprise. On the chart, this restriction is denoted with the point $B$ on the $X$-axis. The area of initial investment and the area of profit can be found by the following formula:

$$
\begin{aligned}
& S_{1}=\int_{0}^{A}\left(k_{2} \sqrt{x}-k_{1} x\right) d x \\
& S_{2}=\int_{A}^{B}\left(k_{1} x-k_{2} \sqrt{x}\right) d x
\end{aligned}
$$


The interval ED shows the maximum effect of implementation of controlled outsourcing (provided the enterprise's capacity is fully loaded). In order to find the length of the interval, we need to substitute the value B in the formulas $y_{1}$ and $y_{2}$, to find the co-ordinates of points $\mathrm{E}$ and $\mathrm{D}$. The resulting equation will have the following view:

$$
E D=k_{1} * B-k_{2} * \sqrt{B}
$$

By solving the equation, we will find the profit that the enterprise will gain due to application of controlled outsourcing at full load of the enterprise's capacity.

For practical application of this methodology, it is necessary to determine the values of the $k_{1}$ and $k_{2}$ ratios. At full outsourcing, the enterprise's costs grow in direct proportion to the growth of the number of cleared goods; therefore, $k_{1}=1$. The ratio applied for building the curve of controlled outsourcing $\left(k_{2}\right)$ depends in the number of factors, namely:

1) the price of customs clearance of one GD by the customs broker;

2) the range of cleared goods;

3) the number of own specialists for customs clearance.

For successful implementation of controlled outsourcing at the initial level, the enterprise needs a specialist who would know at least basic principles of customs legislation. A broker would not offer anything; it just executes the client's order according to its instructions. And if one does not know that there are various customs procedures that allow decreasing customs duties considerably, and various types of GD, he will make the simplest declaration of import for domestic consumption or export.

Availability of at least one specialist for customs clearance will be sufficient for successful implementation of controlled outsourcing at the basic level. Further development of outsourcing of services in the customs sphere should be implemented in several stages (Figure 3).

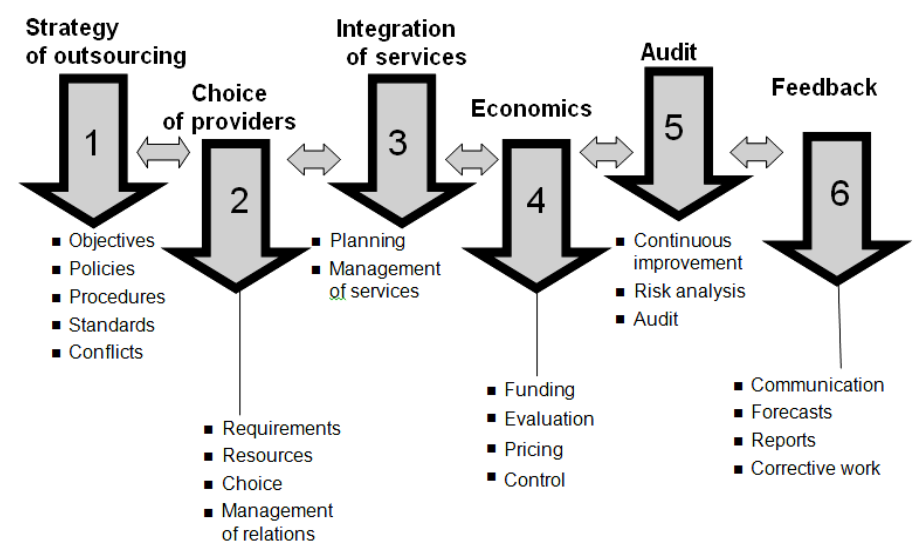

Figure 3. The model of stage-by-stage implementation of controlled outsourcing of services in the customs sphere

Initially, the foreign trade operator must determine the main objectives of implementation of controlled outsourcing, develops standards and requirements, and determines the structure and the functions of its own customs clearance division.

At the next stage, based on the analysis of the work conditions of customs brokers, their capacity and credibility, it should select partners for customs clearance. Besides, it should determine the scope of operations associated with movement of goods across the customs border, which the company is about to outsource.

At the third stage, the conditions and aspects of interaction of the client and the customs broker in the course of the international economic activity are formulated.

The fourth stage includes solution of all economic issues related to interaction with the company that renders services in the customs sphere. It also includes analysis of the economic effect of controlled outsourcing application. 
In the course of the interaction, it is necessary to hold periodical control of obligations fulfillment, evaluation of the existing risks, annual audit. Also, the enterprise should permanently study the existing practice of customs clearance, develop and implement new efficient methodology of cutting the enterprise's costs.

Implementation of the suggested model will allow an enterprise to cut costs associated with movement of goods across the customs border considerably, as well as improve the efficiency of its activity, and increase the profit consequently.

At selection of the method of customs operations, it is not enough to just compare the costs for declaration, as the foreign operations department even at the same expenses for routine operations is able to increase the profit of international economic activity considerably by application of innovative solutions, where the functions of the customs broker do not include seeking such opportunities.

\section{Discussion}

Scientific papers of various authors have sufficient coverage of the issues of international economic activity management, but few efforts are made to analyze the issues of rendering services in the customs sphere. V. Yu. Dianova and V. V. Makrusev considered the conceptual provisions of rendering services in the customs sphere and developed a definition of customs services as services rendered by customs authorities and companies engaged in the customs sphere (Dianova \& Makrusev, 2005).

Being an expert in the issues of theory and methodology of the systems of customs processes management, S. V. Baramzin is the founder of the theory of the customs activity quality management (Baramzin, 2004), which later was studied and added by contemporary economists (Gupanova, 2011, 2012).

At the same time, currently domestic and foreign publications have failed to develop sufficiently the theoretical principles of organization and economics of services in the customs sphere. Despite growing interest of scientists to this issue, the organizational conditions that would contribute to development of services in the customs sphere and their practical application as well as the issues of ensuring strong competitiveness of the services in the customs sphere (including those by application of the most advanced forms of customs clearance and customs control) have not been researched in full.

The existing practice of assignment of services in the customs sphere to outsourcers is not supported by relevant theoretical research. Foreign publications studying outsourcing emphasize its application in the sphere of information technology (Lacity \& Willcocks, 2000; Dibbern et al., 2004). The Russian Banking Encyclopedia provides the following definition: "outsourcing is the type of functional computer services rendered by a specialized firm to its clients (banks, insurance companies, exchanges, etc.)" (Lavrushina, 1995). This definition is very outdated because outsourcing currently is not limited to computer services and is applied in many sectors of the economy. As a rule, scientific publications consider issues of application of full or partial outsourcing.

\section{Summary}

The foreign trade operations of enterprises are described by the vast diversity of issues in the customs sphere. The practice of customs activities suggests various methods of their solution, which are implemented with the help of individual innovative solutions. The whole diversity of innovations in the customs sphere can be evaluated and efficiently used within the framework of controlled outsourcing.

Implementation of controlled outsourcing will allow importers and exporters to optimize their customs clearance activity, apply more beneficial treatments, declaration forms, and electronic customs clearance systems, thus cutting overall expenditures and increasing the enterprise's profit.

The article contains a comparative characteristic of full, partial, and controlled outsourcing, reveals the advantages of controlled outsourcing, and analyzes expenditures of its application. The practical applications of the theoretical developments will be facilitated with the suggested model of stage-by-stage implementation of controlled outsourcing. The lines of further research should be the development of the methodology of implementation and utilization of controlled outsourcing in the course of international economic activity, and the issues of organizational buildup and subjective decomposition of these processes.

\section{References}

"Survey to determine the percentage of national revenue represented by customs duties." (n. d.). World Customs Organization. Retrieved July 1, 2014, from http://www.wcoomd.org

Anikin, B. A. (2003). Outsourcing: Creation of highly efficient and competitive organizations. Moscow: INFRA-M, 2003. Print. 
Baramzin, S. V. (2004). Management of customs activity quality. Moscow: RIO RTA, 2004. Print.

Cassidy, G. (1994). Constructing out. Ontario: Kingston.

Chapman, R. B., \& Andrade, K. (1998). Insourcing after the Outsourcing: Missirvival Guide. New York: American Management Association, 1998. Print.

Dianova, V. Y. (2005). Marketing of customs services. Moscow: RIO RTA, 2005. Print.

Dibbern, J. (2004). Information systems outsourcing: A survey and analysis of the literature. ACM SIGMIS Database Fall, 102. Print. http://dx.doi.org/10.1145/1035233.1035236

Fedorenko, R. V. (2008). Options of outsourcing at customs declaration of goods. Herald of the Russian State Trade and Economics University, 126-131. Print.

Grainger, A. (2014). Measuring-Up Customs: A Trade Compliance Cost Perspective. Social Science Research Network. Retrieved July 3, 2014 from http://www.ssrn.com/abstract=2395325

Gupanova, Y. E. (2011). Current issues of management of the customs services quality. Herald of the Russian Customs Academy, 1, 5-12. Print.

Gupanova, Y. E. (2012). About the essence and the content of the concept "the quality of customs services". Voprosy novoy ekonomiki, 1, 69-79. Print.

Henkel, C. B., Hesch, R., \& Kroger, F. (2000). Dual Restructuring: A Two-way Route to Survival and Competitive Advantage. New York: St Martin's Press.

Heywood, J. B. (2002). Outsourcing: Looking for competitive advantages. Moscow: Williams, 2002. Print.

Johnston, R., \& Clark, G. (2005). Service Operations Management: Improving Service Delivery. Harlow, England: Pearson ation Limited, 2005. Print.

Khramtsova, E. R. (2010). Transportation express services as an element of logistics. Herald of URFU (Series: Economics and Management), 2, 79-86.

Kotler, F., Armstrong, G., \& Sonders, D. (2004). The theory of marketing. Moscow: AST, 2004. Print.

Lacity, M. C., \& Willcocks, L. (2000). Global Information Technology Outsourcing. Search of Business Advantage (p. 368). New York: John Wiley \& Sons, Inc., 2000. Print.

Lavrushin, O. I. (Ed.). (1995). The Russian banking encyclopedia. Moscow: ETA, 1995. Print.

Llanto, G. M., Navarro, A. M., Detros, K. C., \& Ortiz, M. K. P. (2013). Customs Brokerage Services and Trade Facilitation: A Review of Regulatory Coherence. Philippine Institute for Development Studies. Retrieved July 3, 2014, from http://www.pids.gov.ph/index.php

Waters, D. (2003). Logistics. An Introduction to Supply Chain Management. New York: Palgrave Macmillan.

\section{Copyrights}

Copyright for this article is retained by the author(s), with first publication rights granted to the journal.

This is an open-access article distributed under the terms and conditions of the Creative Commons Attribution license (http://creativecommons.org/licenses/by/3.0/). 